\title{
Developing Affective Instrument Based on Performance in Extracurricular Swimming
}

\author{
Rahma Afdhilla Nasution \\ Master Program in Sport Sciences \\ State University of Yogyakarta \\ Yogyakarta, Indonesia \\ Rahmanasution13@gmail.com
}

\author{
Pamuji Sukoco \\ Faculty of Sport Sciences \\ State University of Yogyakarta \\ Yogyakarta, Indonesia \\ Pamuji_Sukoco@uny.ac.id
}

\begin{abstract}
-this research aims to formulate an affective construct of social values for students who took part in extracurricular swimming in primary school, arrange the indicator instrument of the affective aspect based on performance during extracurricular swimming at primary school, and develop an instrument model of affective aspect based on the performance of the students who joined extracurricular swimming at primary school. This research is based on the developmental research of the affective aspect instrument based on the performance of high graders in primary schools. The research applied the developmental model from Thiagarajan, which was known for values, which are the 4D's - Define Design, Development, and Dissemination. The research subjects were primary school students in Yogyakarta who joined extracurricular swimming at school. The techniques used for data analysis in this research were the qualitative covering data reduction, data presentation, and conclusion drawing. The result of affective values construct in extracurricular swimming for primary school students was collected in form of power struggle. The indicator of the affective aspect instrument based on performance in extracurricular swimming was described based on 2 factors namely; intrinsic and extrinsic. The Intrinsic factor consisted of interest and persistence indicators, while the extrinsic factor consisted of family, friend and coach. The development of an affective aspect instrument model based on performance in extracurricular activity in primary schools comprised of some key steps such as the definition by conducting analysis for needs, the field study through observation of extracurricular activity, and the literature study. The product-designing step was conducted by arranging the initial product design followed by arranging the product of the affective scoring instrument, which served as an initial draft instrument of affective scoring. Next, judgment from experts was conducted for the initial product testing for further suggestions. The trial for the game model was conducted two times in a big and small scale. The result of the developing affective scoring instrument based on the performance in extracurricular swimming in primary schools had met the validity and reliability criterion, so, it was suitable to be used as a scoring instrument.
\end{abstract}

Keywords-affective, extracurricular swimming, primary school

\section{INTRODUCTION}

The sporting extracurricular activities is an activity to channel, develop and accommodate students' potency as well as to improve their ability in terms of intelligence (cognitive), socialization (affective) and skill (psychomotor) that contributes to the process of character building. Extracurricular learning is a type of learning that is entirely outside the scheme of the child's normal learning schedule that helps the development of students in accordance with their need, potency, talent, and their interests through the activities provided in school [1].

The regulation of National Education Ministry of the Republic of Indonesia No. 39, Year 2008 on Student Development, in Article 1 of the Law mentioned that the purposes of student development related to extracurricular sporting activities are (1) to optimally develop potencies of students promoting talent, interest, and creativity; (2) to Consolidate students' personality to realize the schools flexibility as an educational environment sparing it from negative influence that are belligerent with educational purposes; (3) actualizing students' potencies in achieving excellent goals related to their talent and interest; and (4) to prepare students to become citizens who have noble characters, who are democratic and respect human rights to promote a mire civil society [5]. Talent and interest on an activity programmed in extracurricular events is expected to be realized to develop and channel the potencies of the students.

The implementation of extracurricular school activities was conducted according to the students' area of interest. The extracurricular activities covered the sectors of cognitive, affective, and psychomotor. This activity was conducted in every school and is in line with the competency created by schools. The development of students' personality is the point of extracurricular activity development where character building has a vital role and position for students to cope in the future society.

Based on these, the researcher studied the measurement instrument based on the affective aspect performance which never existed, so, the researcher would develop the swimming activity in extracurricular events. The social values are measured using the affective instrument which could be understood by users, objective by nature, valid, reliable and easy to interpret. Swimming as an extracurricular activity in primary schools aims to develop the affective aspect of students for better character building in the future. 


\section{METHOD}

This research used the development model approach from Thiagarajan which is known for 4D's namely Define, Design, Development, and Dissemination in Sugiyono (2015:37). The subjects of this research were students of high grades at primary schools. The users of this affective scoring instrument were the coaches of the extracurricular swimming in primary schools. The location of this research was in the Special Region of Yogyakarta province, at primary schools with swimming extracurricular activity, they include schools like Kanisius Demangan Baru, Muhammadiyah Pakel, Muhammadiyah Sagan, and Pangudi Luhur.

\section{RESULTS AND DISCUSSION}

\section{A. Product Trial Result}

The research foremost defined the analysis of the need, field study through observation of extracurricular activities, and the literature study. The next step was the product designing which was carried out by arranging the initial product plan continued by the designing affective scoring instrument into an initial draft. The Initial draft of the affective scoring instrument covered the power struggle variable which consisted of 2 factors namely intrinsic factor and extrinsic factor. Intrinsic factor covered the interest indicator of extracurricular activities and persistence. Nevertheless, the extrinsic factor covered the family indicator, friends, and coach. Overall, the instruments were explained in 34 statements. Experts tested the initial draft of the arranged product to obtain suggestions from them.

The validation test was based on the initial draft or the affective scoring instrument which includes fixing ambiguous and unclear statements. Next, for clarity, the favorable and unfavorable words were separated. The result of draft was reviewed again by an expert validator and the initial draft of the affective scoring instrument was stated proper to be followed up in the field test in either small or large scale.

\section{B. Small Scale Test Result}

The test result of the scale test showed 1 validity test of instrument out of 34 questions, they were all valid as $\mathrm{r}$ cal $>$ $r$ table. It can be concluded that all the questions were proper and could be used as affective aspect scoring component. From the results of the small scale, there was no question removed or decreased because they were all valid. Next, the reliability test for the instrument was conducted using Alpha Cronbach as follows.

TABLE I. THE RESULT OF SMALL SCALE CRONBACH'S ALPHA RELIABILITY TEST

\begin{tabular}{|c|c|}
\hline Cronbach's Alpha Coefficient & Description \\
\hline 0.989 & Reliable \\
\hline
\end{tabular}

Based on Table 15, the value of Cronbach's Alpha coefficient was of 0.989 where the score was $>0.6$; so it can be concluded that the developed affective instrument was reliable and useable. The data of small-scale inter-rater reliability test was also performed to determine the consistency level or the inter-rater constancy in valuing students' affective aspect. The Reliability test of the interrater was seen from the coefficient test of the interclass correlation. The Inter-rater reliability test was done by comparing the two results of training scoring on students' affective aspect in small-scale test. The result of inter-rater reliability test of small-scale test is as follows.

TABLE II. THE RESULT OF SMALL SCALE INTER-RATER RELIABILITY TEST

\begin{tabular}{|c|c|}
\hline Correlation Coefficient & Description \\
\hline 0.914 & Reliable \\
\hline
\end{tabular}

Based on the inter-rater reliability test on the table above, the value of the correlation coefficient was of 0.914 , it shows a high value of inter-rater reliability. It means that the developed instrument of the affective scoring was reliable to be used. The conclusion of the small-scale test result showed 34 questions were valid in the affective scoring instrument, making it reliable and proper to be used for the large-scale test.

\section{Large Scale Test Result}

The results of the large scale tests showed a total of total of 34 questions was valid as the value of $r$ count $>r$ table in the validity test of the affective scoring instrument, so, all the questions could be used as affective research instrument.

Next, the reliability test for the instrument used the Alpha Cronbach is as follows;

TABLE III. THE RESULT OF BIG SCALE CRONBACH'S ALPHA RELIABILITY TEST

\begin{tabular}{|c|c|}
\hline Cronbach's Alpha Coefficient & Description \\
\hline 0.959 & Reliable \\
\hline
\end{tabular}

Based on Table 3 above, the value of Cronbach's Alpha coefficient was of 0.959 where that value was $>0.6$. Therefore, it can be concluded that the developed affective scoring instrument was reliable and proper to be used.

Inter-rater reliability test was seen from the interclass correlation of the coefficient test. The inter-rater reliability test was carried out by comparing the two results of every coach's scoring on the students' affective aspect in the largescale test. The result of the large-scale inter-rater reliability test is as follows;

TABLE IV. THE RESULT OF BIG SCALE INTER-RATER RELIABILITY TEST

\begin{tabular}{|c|c|c|}
\hline Coach & Correlation Coefficient & Description \\
\hline Coach 1 & 0.953 & Reliable \\
\hline Coach 2 & 0.981 & Reliable \\
\hline Coach 3 & 0.886 & Reliable \\
\hline Coach 4 & 0.613 & Reliable \\
\hline
\end{tabular}

Coach 1: male coach of SD Muhammadiyah Sagan (Bintang Ristanto S.Pd)

Coach 2: female coach of SD Muhammadiyah Sagan (Septi Kurnia, S.Pd)

Coach 3: male coach of SD Muhammadiyah Pakel (Kholidin, S.Pd)

Coach 4: female coach of SD Muhammadiyah Pakel (Mela S, S.Pd) 
The result the values of the correlation coefficient from coach 1 is 0.953 , coach 2 is 0.981 , coach 3 is 0.886 and coach 4 is 0.613 . Based on the inter-rater reliability test from table above, the coefficient value of correlation is $>06$; it shows a high inter-rater reliability value. This means that the instrument of the developed affective scoring was reliable to be used. The result also showed high reliability values which means the instrument of the consistency level research or inter-rater constancy in scoring students' affective aspect was proper to be used.

\section{Effectiveness Test Result}

The next step was the final data collection (post-test) in the next meeting. The Effectiveness test was analyzed by using the t-test. The result of the t-test of the affective aspect instrument implementation is as follows.

TABLE V. THE T-TEST DATA RESULT OF THE AFFECTIVE ASPECT SCORING INSTRUMENT ON THE PERFORMANCE OF EXTRACURRICULAR SWIMMING IN PRIMARY SCHOOLS

\begin{tabular}{|c|c|c|c|c|}
\hline Observation & Average & t calculate & Sig. & Description \\
\hline Pre-test & 133.70 & \multirow{2}{*}{3.236} & 0.010 & Significant \\
\hline Post-test & 141.70 & & & \\
\hline
\end{tabular}

Based on the results of the t-test on student's affective aspect, the t-cal. was 3.236 and significance value was 0.010 . Hence, since the significant value of examination on students' affective aspect was less than $0.05(\mathrm{p}<0.05)$, a conclusion can be drawn that there was a significant improvement of the affective aspect on students joining the extracurricular swimming activities. The students' affective aspect score from the pre-test experienced significant improvement in the post-test. From the results, it can be interpreted that the affective aspect-scoring instrument in extracurricular swimming activities in primary schools were effective and could improve the student's affective attitude.

\section{E. Final Product Review}

The Final product of this research was the affective scoring instrument based on the small and large scale and the performance in extracurricular swimming activities in primary schools. There were some changes from initial draft of the instrument previously arranged. The change and revision conducted were based on suggestion and correction from expert validators and coaches who were directly involved in the implementation of affective the scoring instrument in the field. The final product of this research is the affective scoring instrument which is based on the performance in extracurricular swimming in primary schools.

\section{F. Research Limitation}

Field observation involved only coaches from schools, if experts were involved in observing and scoring the students' affective aspect in extracurricular swimming activities. The Weather factor was also an obstacle due to rains that made students abscond from the exercises.

\section{CONCLUSION}

The affective values construct in extracurricular swimming in primary schools obtained from the result of the research was the power struggle; this is the ability to struggle and overcome problems, obstacles, and difficulties in extracurricular swimming activities. The indicators of the affective aspect instrument were based on performance in the extracurricular swimming activities were 2 factors namely; intrinsic and extrinsic. The Intrinsic factor consisted of interest and persistence indicators; while the extrinsic factor consisted of family, friends and coaches.

\section{ACKNOWLEDGMENT}

The authors would like to thank Yogyakarta State University for the funding support.

\section{REFERENCES}

[1] Djemari Mardapi, "Measurement, Assessment and Evaluation of Education". Yogyakarta, Parama, 2017.

[2] H. Hairina, Suharnan, "Concept of adversity quotient and student learning independence", Journal of Psychology, 2013, vol. 8, no. 1, pp. 619-632.

[3] A. R. Mansyur, Suratno, "Assessment of Learning in School". Yogyakarta, Pustaka Belajar, 2015.

[4] Y. Noor, A. Rabiatul, M. Harpani, "Implementation of extracurricular activities in order to develop characteristic values to be a good citizen in sma korpri banjarmasin. Journal of Citizenship Education, 2016, vol. 6, no. 11 .

[5] Regulation of the Minister of National Education of the Republic of Indonesia Number 39 Year 2008 regarding Student Development.

[6] J. W. Santrock, "Adolescence: youth development", Penerjemah Shinto B. Adelar, Jakarta, Erland, 2003.

[7] Sugiyono, "Research \& Development Method". Bandung, Alfabeta, 2015).

[8] Suradi, "Formation of student character through application of discipline of school order". Journal of Research and Conceptual, 2017, vol. 2 , no. 4

[9] Trianto, "Design of thematic learning for early childhood TK/RA \& early childhood primary school/MI". Jakarta, Prenada Media Group, 2015 .

[10] Y. A. Wibowo, F. D. Andriyani, "Development of school school extracurricular”. Yogyakarta, UNY Press, 2015. 